\title{
Recovery of above-ground tree biomass after moderate selective logging in a central Amazonian forest
}

\author{
Tatsuya Otani ${ }^{(1)}$, \\ Adriano JN Lima ${ }^{(2)}$, \\ Rempei Suwa ${ }^{(3)}$, \\ Marcio RM Amaral ${ }^{(2)}$, \\ Shinta Ohashi ${ }^{(4)}$, \\ Alberto CM Pinto ${ }^{(5)}$, \\ Joaquim Dos Santos ${ }^{(2)}$, \\ Takuya Kajimoto ${ }^{(4)}$, \\ Niro Higuchi ${ }^{(2)}$, \\ Moriyoshi Ishizuka ${ }^{(4)}$
}

\begin{abstract}
We examined the recovery and dynamics of living tree above-ground biomass (AGB) after selective logging in an Amazonian terra firme forest managed by a private company. The forest consisted of 24 blocks (including one set aside for conservation) selectively logged in different years on a managed schedule. Trees $\geq 10 \mathrm{~cm}$ in diameter at breast height (dbh) were surveyed in 2006 in 192 0.25-ha plots, in 2010 in 119 plots, and in 2012-2013 in 54 plots. A logistic growth model factoring in logging dynamics and mean AGB of a block in these years was established. Referencing the mean AGB of the unlogged forest, the model indicated that the logged forest would take on average 14 years to regain its preharvest AGB after selective logging at 1.9 trees $\mathrm{ha}^{-1}(\mathrm{dbh}>50 \mathrm{~cm})$. In 2010 and 2012-2013, the AGB increased significantly for small and large trees $(10-20 \mathrm{~cm}$ and $>60 \mathrm{~cm} \mathrm{dbh}$, respectively) in the logged forest. In contrast, it decreased significantly for medium-sized trees $(30-50 \mathrm{~cm} \mathrm{dbh})$ in the unlogged forest. Comparisons with the previous studies mainly conducted in the other regions of Amazon suggested that the estimated AGB recovery period with moderate logging intensity was almost appropriate and likely acceptable to forest managers.
\end{abstract}

Keywords: Annual Increment, Dynamics, Logistic Growth, Recovery Period, Terra Firme Forest

\section{Introduction}

Forests in the Amazon basin are estimated to hold 86 petagrams (Pg) of carbon (C - Saatchi et al. 2007), which ac counts for roughly $10 \%$ of the total carbon stored in forests worldwide $(861 \pm 66 \mathrm{Pg} \mathrm{C}$ - Pan et al. 2011). However, carbon stocks in the Amazon basin have dramatically decreased because of deforestation and forest degradation. Conversion of forest to farmland, selective logging in natural forests, and forest fragmentation (Laurance et al. 1997, Asner et al. 2005, Broadbent et al. 2008) have all contributed to this decline in global carbon stocks. Selective logging is still widely used in the Amazon region because of high tree species diversity in natural forests and limited markets for timber from less desirable species. Carbon stock, species diversity, and timber yield from subsequent harvests have declined after selective logging (Putz et al. 2012). The carbon emission from logging in Brazil was assessed at $24.9 \mathrm{Tg} \mathrm{C}^{-1}$, which was $>15$ times that of other Latin American countries that are part of Amazonia (Bolivia, Guyana and Suriname - Pearson et al. 2014). Another study based on remote sensing data estimated the emission of al-

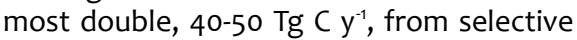
logging in the Brazilian Amazon, over a period expected to last two to three decades (Huang \& Asner 2010). Therefore, selective logging and subsequent biomass loss in the Brazilian Amazon could substantially accelerate climate change.

Modern mechanized selective logging can cause serious injury to residual trees
(1) Shikoku Research Center, Forestry and Forest Products Research Institute (FFPRI), Kochi (Japan); (2) National Institute of Amazonian Research, Manaus, Amazonas (Brazil); (3) Kansai Research Center, FFPRI, Kyoto (Japan); (4) FFPRI, Tsukuba, Ibaraki (Japan); (5) Federal University of Amazonas, Manaus, Amazonas (Brazil)

@ Tatsuya Otani (tatsuyao@affrc.go.jp)

Received: Jun 25, 2017 - Accepted: Feb 08, 2018

Citation: Otani T, Lima AJN, Suwa R, Amaral MRM, Ohashi S, Pinto ACM, Dos Santos J, Kajimoto T, Higuchi N, Ishizuka $M$ (2018). Recovery of above-ground tree biomass after moderate selective logging in a central Amazonian forest. iForest 11: 352-359. - doi: 10.3832/ifor2534-011 [online 2018-05-04]

Communicated by: Rodolfo Picchio
(Uhl \& Vieira 1989). Injured trees experience a threefold mortality rate 5 to 10 years after logging (Picard et al. 2012). Carbon emission from logging activities can arise from the damage to surrounding vegetation and infrastructure rather than from the timber itself (Pearson et al. 2014). One option for reducing net carbon emissions is to reduce the damage to residual forests during selective logging operations, thereby retaining carbon in the biomass (Pinard \& Putz 1996). Since the early 1950 s, sustainable forest management (SFM) for timber production has been a potential tool for the conservation of large areas of tropical forest (Sist et al. 2012). Reduced impact logging (RIL) techniques have proven effective in decreasing damage and enhancing the recovery of logged forests. For example, collateral damage in forests after selective logging can be reduced by up to $50 \%$ with RIL techniques (Pinard \& Cropper 2000). In addition to this approach, strict regulation of logging intensity and expanded protection of large and commercial trees have been proposed to achieve SFM (Sist \& Ferreira 2007, Peña-Claros et al. 2008, Sist et al. 2014).

Despite low-intensity harvesting, forests lose carbon stock from damaged trees that die several years after logging. Conversely, selectively logged forests regain biomass and act as a carbon sink through the recovery process. Thus, net biomass accumulation results from the balance between the growth of residual trees, recruitment of new trees, and tree mortality. For example, 
living tree biomass constantly increased for 14 years after selective logging in the eastern Amazon (West et al. 2014). In contrast, biomass constantly decreased for 3 years in the eastern Amazon, as mortality outpaced growth (Figueira et al. 2008). In addition, annual biomass increments fluctuated over time after logging (Mazzei et al. 2010, Sist et al. 2012). Even under SFM, biomass recovery after harvesting can be complicated, with wide variation in the recovery period. The recovery period is directly relevant to management policies that regulate allowable harvest volume and cutting cycles (Rutishauser et al. 2015). More examples of biomass regrowth after selective logging are needed to accurately measure carbon emissions in the Amazon basin and to achieve true SFM including carbon stock. In particular, available information on RIL-operated forests is essentially lacking in the central Amazon.

Monitoring of forest recovery after a disturbance is time intensive; therefore researchers use chronosequencing to analyze the relationships between recovery time and biomass or carbon stock in forests (Fonseca et al. 2011, Kashian et al. 2013). However, chronosequence data only permits inferences of successional change and do not facilitate the direct analysis of underlying processes that mediate the change, such as growth, mortality and recruitment (Chazdon et al. 2007). The combination of chronosequencing and dynamics analyses can provide an effective tool to explain the changes in biomass (Mora et al. 2015). In the present study, we examined the recovery and dynamics of aboveground biomass (AGB) after selective logging under SFM in a typical terra firme forest managed by a private company in the central Amazon. We used a chronosequence data set of logged forest blocks partly combined with repeated measurement data in some of the plots. First, we estimated the AGB recovery period by applying a logistic growth model to determine whether the current management scheme could sustain tree biomass. Second, we focused our analysis of the data on how the AGB recovery process varied by tree size classes after selective logging, that is, the contribution of trees of various sizes to AGB recovery after selective logging. Finally, we compared the relationship between logging intensity and the AGB recovery period with data from previous

studies, and discussed appropriate methods of RIL in the Amazon basin for achieving SFM.

\section{Methods}

\section{Study site}

The study site was located in a managed forest owned by Precious Woods Amazon (PWA) Ltd. that was $40 \mathrm{~km}$ west of Itacoatiara, Amazonas, Brazil. PWA manages approximately 75,000 ha $\left(02^{\circ} 43^{\prime}-03^{\circ} 04^{\prime} \mathrm{S}\right.$, $58^{\circ} 31^{\prime}-58^{\circ} 57^{\prime} \mathrm{W}$ - FAO 2002) of dense ombrophilous terra firme forest that is dominated by species belonging to the Burseraceae, Lauraceae, Lecythidaceae, Leguminosae, and Sapotaceae families. The region has a mean annual temperature of $26{ }^{\circ} \mathrm{C}$ and a mean annual rain fall of $2,200 \mathrm{~mm}$ (FAO 2002). Excluding conservation areas, catchments, and buffer zones, the forest is divided into 25 annual operating blocks of approximately 2,100 ha each, which has been selectively logged since 1995 (Webster \& Callejon 1998). PWA's selective logging scheme, targeting SFM, is based on the CELOS Management System (CMS - De Graaf \& Poels 1990), and has been adapted for the Amazon area. The RIL techniques used by PWA include the mapping target trees, well-designed forest roads and skidder trails, preharvest liana cutting and directional felling. PWA was certified by the Forest Stewardship Council in 1997, and under PWA's management plan, trees with a trunk diameter at breast height ( $\mathrm{dbh}$ ) of $>50 \mathrm{~cm}$ (preferably $>60 \mathrm{~cm}$ ), which include about 40 species, are subjected to selective logging at a maximum wood volume of $30 \mathrm{~m}^{3} \mathrm{ha}^{-1}$ in a harvest cycle of 25 years (FAO 1997, 2002 - personal communications in PWA). Assuming that the average log volume per tree is $6.3 \mathrm{~m}^{3}$ in the Brazilian Amazon (Uhl \& Vieira 1989, FAO 1997), $30 \mathrm{~m}^{3} \mathrm{ha}^{-1}$ is equal to a harvesting intensity of 4.8 logs ha-1. Although a detailed record of harvested timbers and volume was unavailable, the field survey described stumps and skidder trails with a mean density of 1.9 stumps ha ${ }^{-1}$ with a mean diameter of $61 \pm 19 \mathrm{~cm}( \pm \mathrm{SD})$, and a mean of $0.9 \pm$ 0.8 skidder trails per plot.

\section{Tree inventory and biomass estimation}

In 2006, 192 study plots measuring $125 \times$ $20 \mathrm{~m}$ ( $0.25 \mathrm{ha})$ were established in randomly selected locations in 24 forest blocks, including a conservation block (Tab.

Tab. 1 - Three different tree inventory studies in a managed terra firme forest in Itacoatiara, central Amazon. (a): Plot size was $125 \times 20 \mathrm{~m}$ ( $0.25 \mathrm{ha}$ ) for all inventories.

\begin{tabular}{lccc}
\hline \multirow{2}{*}{ Statistic } & \multicolumn{3}{c}{ Inventory year } \\
\cline { 2 - 4 } & 2006 & 2010 & $\mathbf{2 0 1 2 - 2 0 1 3}$ \\
\hline Number of plots ${ }^{\text {(a) }}$ (Unlogged plots) & $192(6)$ & $119(20)$ & $54(5)$ \\
Number of forest blocks & 24 & 19 & 16 \\
Mean number of plots per block \pm SD & $8.0 \pm 2.9$ & $6.3 \pm 3.5$ & $3.4 \pm 0.9$ \\
Range of time since logging (yrs) & $1-11$ & $5-15$ & $8-18$ \\
\hline
\end{tabular}

1). Except for the protected area, these blocks have been selectively logged since 1995; therefore, by 2006, the period after logging in each block ranged from 1 to 11 years. The $\mathrm{dbh}$ of all trees was $\geq 10 \mathrm{~cm}$ as recorded for the plots. Plot locations were recorded by global positioning system (GPS) receivers because metal tags and survey poles could not be used.

In 2010, according to the GPS coordinates, 119 plots of the same size as those in 2006 were arranged again at a location that either overlapped or was adjacent to the plots established in 2006, and the trees were marked with spray paint on trunk. Of these 119 plots, 54 were revisited in 2012 or 2013, and trees were inventoried again.

The dry above-ground biomass (AGB, kg) of each tree (excluding palms and lianas) was estimated with the allometric equation (Silva 2007) using dbh (cm - eqn. 1):

$$
A G B=1.3278 \cdot d b h^{1.9156}
$$

This allometric equation was developed from data of 494 harvested trees in the ZF2 experimental forest at the Instituto $\mathrm{Na}$ cional de Pesquisas da Amazônia, a primary forest in the central Amazon (Silva 2007).

\section{Statistical analysis}

$A G B$ per plot was defined as the sum of individual $A G B$ values. By comparing the two sequential inventory data from 2010 and 2012-2013, fates of individual trees were surveyed and $A G B$ changes due to tree growth, recruitment, and mortality were examined in each plot.

The mean $A G B$ in each block was obtained by the bootstrap method, in which observed values from four randomly selected plots in a block during the same inventory year were added up with 5,000 replicates to calculate the mean $A G B$ in each block. This method proved effective in controlling for the wide variation in $A G B$ $\mathrm{ha}^{-1}$ that was caused by the huge trees present in a plot.

Because we found a significant positive correlation between time after logging and mean block-level AGB in the 2006 data but not in the 2010 or 2012-2013 data, we used a logistic growth model to represent the recovery process of AGB after selective logging (eqn. 2):

$$
A G B=\frac{\alpha_{i} \cdot K}{1+\exp (a-b \cdot Y e a r)}
$$

where $A G B\left(\mathrm{Mg} \mathrm{ha}^{-1}\right)$ is the mean $\mathrm{AGB}$ of a forest block in an inventory year; Year is the number of years after selective logging; $\alpha_{i}$ is a random effect for the $i$-th block, following a log-normal distribution with mean 1.0, and variance was assumed to follow a uniform distribution ranging from 0 to 1,$000 ; K, a$, and $b$ are estimated parameters where we assumed a gamma distribution with value of 0.001 for both the shape and scale parameters for $K$, and a normal distribution with mean $O$ and variance 1,000 for $a$ and $b$, respectively. Parameters 
were estimated by Bayesian analysis with a Markov Chain Monte Carlo (MCMC) algorithm. The $M C M C$ procedure was run for 10,000 iterations after a burn-in of 2,000 iterations. Convergence of MCMC was validated visually using Convergence Diagnostic and Output Analysis (CODA - Plummer et al. 2006) and Gelman \& Rubin's convergence diagnostic (<1.05) for all parameters, including the random effect (Gelman \& Rubin 1992). Because we had no data for the preharvest AGB of the logged blocks, we defined the $A G B$ recovery period as the time needed for the $A G B$ derived from the logistic growth model to reach the mean AGB of the unlogged block. Computations were performed in the JAGS 3.2.0, R 3.0.3, R2WinBUGS and rjags software.

\section{Results}

\section{AGB increase after logging}

The mean AGB per logged block ranged from 226.4 to $314.3 \mathrm{Mg} \mathrm{ha}^{-1}$ in 2006, 259.7$341.0 \mathrm{Mg} \mathrm{ha}^{-1}$ in 2010, and $244.6-342.8 \mathrm{Mg}$ ha $^{-1}$ in 2012-2013 (Fig. 1a). The 2006 data showed a positive significant linear correlation between time after selective logging and mean $A G B$ in each block $(r=0.63, P=$ 0.0011 , df = 21), but the 2010 and 2012-2013 data showed no significant relationship ( $P$ $>0.05$ ).

The mean AGB in the unlogged block was estimated to be $304.4 \mathrm{Mg} \mathrm{ha}^{-1}$ (240.9-368.8 $\mathrm{Mg} \mathrm{ha}{ }^{-1}, 95 \%$ confidence interval $[\mathrm{Cl}]$ by bootstrapping) in 2006, $308.2 \mathrm{Mg} \mathrm{ha-1}$ (255.4-356.0 $\mathrm{Mg} \mathrm{ha}^{-1}$ ) in 2010, and 298.9 Mg $\mathrm{ha}^{-1}\left(271.5-319.7 \mathrm{Mg} \mathrm{ha}^{-1}\right)$ in 2012-2013. These results suggest that there was no significant difference $(95 \% \mathrm{Cl})$ among the mean $A G B s$ during any survey year in the unlogged block. The overall average of AGB was $306.4 \mathrm{Mg}^{-1}$ in the unlogged block.

The parameters in the logistic growth model had estimated median values of $a=$ -0.902, $b=0.277, K=309.2$ (Tab. 2), and $\alpha_{i}=$ $0.950-1.036$. The estimated value of $K$, the upper limit of AGB growth, was very close to the mean value of the unlogged forest block (306.4 Mg ha-1), which was within the 95\% credible interval of $\mathrm{K}$ (295.7-339.2 Mg $\mathrm{ha}^{-1}-\mathrm{Tab} .2$ ). As indicated by the regression line, the logged forest would regain its $\mathrm{AGB}$ at a rate of $15.4 \mathrm{Mg} \mathrm{ha}^{-1} \mathrm{y}^{-1}$ one year after logging, $13.1 \mathrm{Mg} \mathrm{ha}^{-1} \mathrm{y}^{-1}$ after 2 years, 7.2 Mg ha ${ }^{-1} \mathrm{y}^{-1}$ after 5 years, and $2.1 \mathrm{Mg} \mathrm{ha}^{-1} \mathrm{y}^{-1}$ after 10 years of logging. The logistic regression curve showed that the AGB of the logged blocks would reach the mean AGB of the unlogged block (306.4 Mg ha-1) 14 years after logging; however, the $95 \%$ credible interval places the range between 9 years to infinity (Fig. 1b).

\section{AGB dynamics of unlogged and logged blocks}

Data collected in 2010 and 2012-2013 showed that the annual increment of $A G B$ was $3.8 \pm 3.3 \mathrm{Mg} \mathrm{ha}^{-1} \mathrm{y}^{-1}($ mean $\pm \mathrm{SD}, \mathrm{n}=30)$ in the logged plots where 5-9 years had passed since selective logging in 2010, and
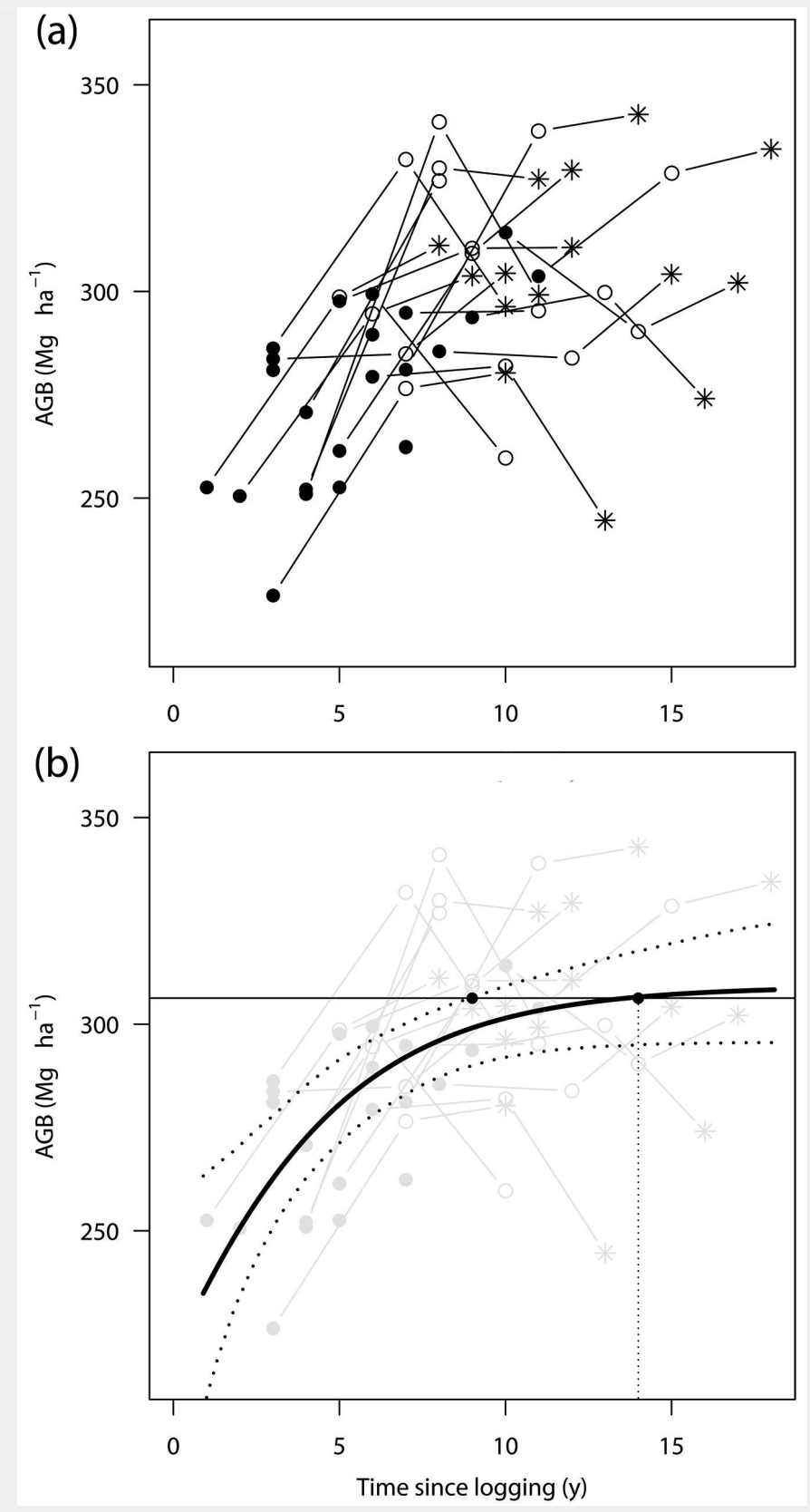

Fig. 1 - Relationship between time after logging and aboveground biomass (AGB) in a managed terra firme forest in Itacoatiara, central Amazon. (a) Mean AGB of each forest block measured after selective logging. Black circle: 2006; white circle: 2010; and asterisk: 20122013. Solid lines join data from the same block. (b) Logistic growth curve of $A G B$ after selective logging. Bold line, estimated logistic growth; dashed lines, the $95 \%$ credible interval; horizontal solid line, mean AGB of an unlogged block (306.4 Mg ha $^{-1}$ ); dashed vertical line, expected AGB recovery period (14 years). See Tab. 2 for details of the logistic curve.

$2.5 \pm 5.2 \mathrm{Mg} \mathrm{ha}^{-1} \mathrm{y}^{-1}(n=19)$ in plots after 1015 years (Tab. 3). Although these values were not significantly different based on the $95 \% \mathrm{Cl}$, the plots measured $5-9$ years after logging showed a marginally larger AGB annual increment than plots measured 1015 years after logging. Under both plot conditions, AGB annual increment was significantly positive. In the earlier- (5-9 years)

Tab. 2 - Posterior mean \pm standard deviation (SD), median, 95\% credibility of parameters and Gelman \& Rubin's convergence diagnostic $(R)$ in a logistic growth model of time after logging and AGB in a managed terra firme forest in Itacoatiara, central Amazon.

\begin{tabular}{lcccc}
\hline Parameter & Mean \pm SD & Median & $\begin{array}{c}95 \% \\
\text { credibility }\end{array}$ & $R$ \\
\hline$a$ & $-0.910 \pm 0.303$ & -0.902 & -1.557 to -0.345 & 1.00 \\
$b$ & $0.287 \pm 0.111$ & 0.277 & 0.106 to 0.539 & 1.00 \\
$K$ & $311.0 \pm 11.40$ & 309.2 & 295.7 to 339.2 & 1.01 \\
\hline
\end{tabular}


Tab. 3 - Annual AGB increment due to tree growth, recruitment, and mortality in unlogged and selectively logged Amazonian forest plots in Itacoatiara, central Amazon. Mean \pm standard deviation $\left(\mathrm{Mg} \mathrm{ha}^{-1} \mathrm{y}^{-1}\right)$. Values in parentheses show the $95 \%$ confidence intervals generated by the bootstrap method (5,000 replicates, $\mathrm{BCa}$ ). Annual AGB increments were derived from inventory data from 2010 to 2012-2013 evaluations. Logged plots were classified by time after selective logging: 5-9 years and 10-15 years by 2010 .

\begin{tabular}{llcccc}
\hline Logging & $\begin{array}{l}\text { Time after } \\
\text { logging }\end{array}$ & Overall & Growth & Recruit & Mortality \\
\hline $\begin{array}{l}\text { Unlogged } \\
(n=5)\end{array}$ & - & $-4.4 \pm 6.5$ & $3.4 \pm 1.3$ & $1.4 \pm 1.1$ & $-9.2 \pm 7.3$ \\
Logged & All & $(-10.5$ to -0.4$)$ & $(2.2-4.2)$ & $(0.7-2.5)$ & $(-16.3$ to -4.4$)$ \\
& $(n=49)$ & $(1.6-4.2)$ & $(5.0-6.3)$ & $(1.0-1.6)$ & $(-5.0$ to -2.9$)$ \\
& $5-9$ years & $3.8 \pm 3.3$ & $5.3 \pm 2.1$ & $1.2 \pm 1.0$ & $-2.8 \pm 2.2$ \\
& $(n=30)$ & $(2.2-5.1)$ & $(4.5-6.4)$ & $(0.8-1.8)$ & $(-3.8$ to -1.9$)$ \\
& $10-15$ years & $2.5 \pm 5.2$ & $5.7 \pm 2.4$ & $1.3 \pm 1.1$ & $-4.4 \pm 4.1$ \\
& $(n=19)$ & $(0.5-4.2)$ & $(5.0-6.7)$ & $(0.9-1.7)$ & $(-6.2$ to -3.2$)$ \\
\hline
\end{tabular}

$\left(-9.2 \pm 7.3 \mathrm{Mg} \mathrm{ha}^{-1} \mathrm{y}^{-1}\right)$, when compared to the logged blocks $\left(-3.8 \pm 3.6 \mathrm{Mg} \mathrm{ha}^{-1} \mathrm{y}^{-1}\right.$ for all logged plots). In addition, the increased annual AGB due to tree growth was significantly smaller in the unlogged block $(3.4 \pm$ $1.3 \mathrm{Mg} \mathrm{ha} \mathrm{H}^{-1} \mathrm{y}^{-1}$ than in the logged blocks $\left(5.6 \pm 2.3 \mathrm{Mg} \mathrm{ha}^{-1} \mathrm{y}^{-1}, 95 \% \mathrm{Cl}\right)$. However, new tree recruitment caused similar increases in AGB in both unlogged and logged blocks $\left(1.4 \pm 1.1\right.$ and $1.3 \pm 1.1 \mathrm{Mg} \mathrm{ha}^{-1} \mathrm{y}^{-1}$, respectively).

Small to medium-sized trees $(10-40 \mathrm{~cm}$ $\mathrm{dbh}$ ) contributed significantly more $A G B$ in

the unlogged block (68\% of the total) than in either logged block groups (53\%-55\%, 95\% $\mathrm{Cl}$ - Fig. 2a). In contrast, large trees (40-60 $\mathrm{cm} \mathrm{dbh}$ ) had significantly less $A G B$ in the unlogged block than in the later-logged blocks (Fig. 2a). The largest tree size class $(>60 \mathrm{~cm} \mathrm{dbh})$ in all block types had wider variations of AGB than smaller tree classes. The unlogged block showed a decreased AGB in all size classes up to $60 \mathrm{~cm} \mathrm{dbh}$, which was also significant in medium-sized trees with $30-50 \mathrm{~cm} \mathrm{dbh}$ ( $95 \% \mathrm{Cl}-$ Fig. 2b). In contrast, the logged blocks showed pos-

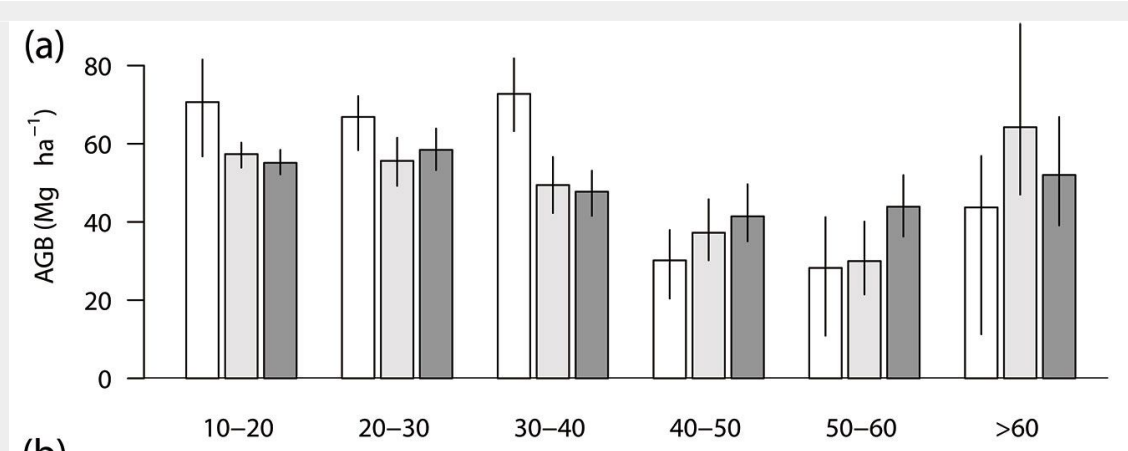

(b)

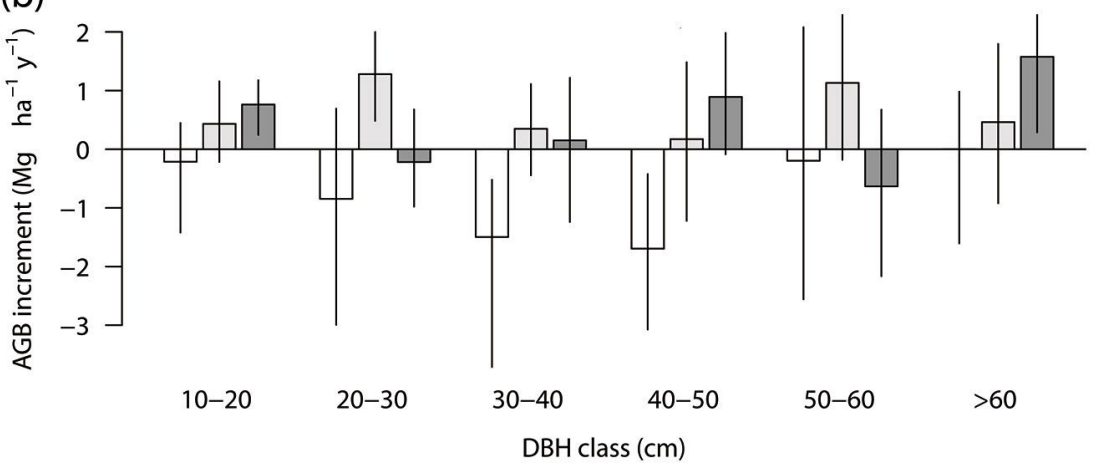

Fig. 2 - Above-ground biomass (AGB) dynamics by diameter at breast height (dbh) size class in the unlogged and logged forest plots in Itacoatiara, central Amazon: (a) AGB ( $M g$ ha-1) in 2010; (b) annual AGB increment $\left(\mathrm{Mg} \mathrm{ha}^{-1} \mathrm{y}^{-1}\right)$ from 2010 to 2012-2013. The logged plots were classified by time after selective logging. White bars, unlogged plots $(n=5)$; light gray bars, logged plots 10-15 y after logging by $2010(n=19)$; dark gray bars, logged plots 5-9 y since logging $(n=30)$. Vertical lines represent the $95 \%$ confidence intervals generated by the bootstrap method (5,000 replicates, $\mathrm{BCa})$. itive AGB increments in all tree size classes, with the exception of the $20-30 \mathrm{~cm}$ and $50-$ $60 \mathrm{~cm}$ dbh classes in the later-logged blocks. These increments were significantly positive in the smallest $(10-20 \mathrm{~cm} \mathrm{dbh})$ and largest $(>60 \mathrm{~cm} \mathrm{dbh}$ ) size classes in the later-logged blocks and in the $20-30 \mathrm{~cm}$ $\mathrm{dbh}$ class of the earlier-logged blocks (Fig. $2 b)$.

\section{Discussion}

AGB stock in unlogged forest block

The estimated mean AGB of the unlogged forest block was 306.4 Mg ha-1. The logistic growth model showed that the AGB of the logged blocks would plateau at $309.2 \mathrm{Mg}$ $h^{-1}$ (Tab. 2, Fig. 1b). These estimated AGB represented potential value for typical terra firme forests in Itacoatiara, but are somewhat lower than those reported for other terra firme forests in the central Amazon. For example, AGB of natural stands in some sites near Manaus reached 320-360 Mg ha-1, as indicated by ZF-2 (Vieira et al. 2004), the Biomass and Nutrient Experiment (BIONTE - Chambers et al. 2004), and the Biological Dynamics of Forest Fragments Project (BDFFP - Laurance et al. 1999; summarized in Tab. 4). In addition, trees in the $10-40 \mathrm{~cm}$ dbh size classes in the unlogged block had a greater proportion of AGB (68\% - Fig. 2a) than trees in the same classes examined in other sites, such as the natural forests in the Reserva Florestal Adolpho Ducke (42\% - De Castilho et al. 2006) and ZF-2 (50\% - Vieira et al. 2004). Soil fertility and topography account for approximately $20 \%-30 \%$ of the variation in AGB in Amazonian terra firme forests (Laurance et al. 1999, De Castilho et al. 2006). At the landscape level in moist terra firme forests, AGB on plateaus with clayey soil tended to be higher than that in valleys with sandy soil (De Castilho et al. 2006, Suwa et al. 2013). Because our study plots were placed randomly in each block to avoid under- or overestimating AGB by favoring particular sites, the apparent $A G B$ bias toward small and medium-sized trees might explain the low AGB measured in this study compared to reports on other forests (Tab. 4).

\section{AGB dynamics in Itacoatiara}

$A G B$ showed a relatively large annual decrease $\left(-4.4 \mathrm{Mg} \mathrm{ha}^{-1} \mathrm{y}^{-1}\right)$ in the unlogged block of Itacoatiara (Tab. 4), due mainly to the mortality of medium-sized trees (30-50 $\mathrm{cm}$ dbh - Fig. 2b). Suwa et al. (2016) reported that the mortality of medium trees that are $40-50 \mathrm{~cm}$ dbh was higher than trees in the other size classes in the unlogged forest of ZF-2, in the central Amazon. The AGB increment due to the growth of surviving trees in the unlogged block (3.4 Mg ha-1 $\mathrm{y}^{-1}$ ) was similar to those reported for the natural terra firme forests in ZF-2 (3.8 Mg ha-1 $\mathrm{y}^{-1}$ - Vieira et al. 2004) and Paragominas in the eastern Amazon (3.9 and 4.3 Mg ha ${ }^{-1} \mathrm{y}^{-1}-$ Mazzei et al. 2010). The 
Tab. 4 - Above-ground biomass (AGB) and annual AGB increment in natural and selectively logged Amazonian forests. (a): Mean \pm standard deviation before harvest in logged forests; (b): mean (range in parentheses due to a temporal fluctuation in the same plot or spatial variation in multiple plots); (RIL): reduced impact logging; (CL): conventional logging.

\begin{tabular}{|c|c|c|c|c|c|c|c|}
\hline \multirow[b]{2}{*}{ Region } & \multirow[b]{2}{*}{ Site } & \multicolumn{2}{|c|}{ Natural forest } & \multicolumn{2}{|c|}{ Selectively logged forest } & \multirow[b]{2}{*}{ Condition } & \multirow[b]{2}{*}{ Reference } \\
\hline & & $\begin{array}{l}\text { AGB }{ }^{(a)} \\
\left(M_{g ~ h a}{ }^{-1}\right)\end{array}$ & $\begin{array}{l}\text { Annual } \\
\text { increment } \\
\text { of AGB }{ }^{(b)} \\
\left(\mathrm{Mg} \mathrm{ha}^{-1} \mathrm{y}^{-1}\right)\end{array}$ & $\begin{array}{l}\text { AGB }{ }^{(a)} \\
\left(M^{\prime} a^{-1}\right)\end{array}$ & $\begin{array}{l}\text { Annual } \\
\text { increment } \\
\text { of AGB }{ }^{(b)} \\
\left(\mathrm{Mg} \mathrm{ha}^{-1} \mathrm{y}^{-1}\right)\end{array}$ & & \\
\hline \multirow[t]{7}{*}{ Central } & \multirow[t]{2}{*}{ ZF-2 } & 360 & -0.15 & - & - & - & Vieira et al. (2004) \\
\hline & & 317 & - & - & - & - & Suwa et al. (2013) \\
\hline & BIONTE & $328 \pm 18$ & $\begin{array}{l}+1.6 \\
(+0.7-+2.2)\end{array}$ & $340 \pm 26$ & $\begin{array}{l}+3.7 \\
(+1.8-+5.7)\end{array}$ & - & Chambers et al. (2004) \\
\hline & \multirow[t]{2}{*}{ BDFFP } & $298 \pm 12$ & +0.6 & - & - & $\begin{array}{l}\text { Partly } \\
\text { fragmented }\end{array}$ & Pyle et al. (2008) \\
\hline & & $356 \pm 47$ & - & - & - & $\begin{array}{l}\text { Partly } \\
\text { fragmented }\end{array}$ & Laurance et al. (1999) \\
\hline & Ducke & 306 & - & - & - & - & De Castilho et al. (2006) \\
\hline & Itacoatiara & 306 & -4.4 & - & +3.0 & RIL & This study \\
\hline \multirow[t]{11}{*}{ East } & \multirow[t]{4}{*}{ Paragominas } & 337 & +1.9 & \multirow[t]{2}{*}{$410 \pm 65$} & \multirow{2}{*}{$\begin{array}{l}+2.6 \\
(-3.5-+10.6)\end{array}$} & RIL & \multirow[t]{2}{*}{ Mazzei et al. (2010) } \\
\hline & & 462 & +0.8 & & & & \\
\hline & & 238 & -0.6 & 260 & +2.8 & RIL & West et al. (2014) \\
\hline & & - & - & 264 & +0.5 & $\mathrm{CL}$ & \\
\hline & \multirow[t]{2}{*}{ Paracou } & $\approx 420$ & +1.0 & $\approx 420$ & $(+0.8-+3.4)$ & $\mathrm{CL}$ & \multirow[t]{2}{*}{ Sist et al. (2012) } \\
\hline & & $\approx 440$ & +1.2 & $\approx 440$ & $(-7.8-+6.0)$ & $\begin{array}{l}\mathrm{CL} \& \\
\text { treatment }\end{array}$ & \\
\hline & \multirow[t]{2}{*}{ Nouragues } & 365 & $\begin{array}{l}+0.4 \\
(-1.9-+2.3)\end{array}$ & - & - & - & \multirow[t]{2}{*}{ Chave et al. (2008) } \\
\hline & & 380 & $\begin{array}{l}+2.3 \\
(+0.9-+3.6)\end{array}$ & - & - & - & \\
\hline & \multirow[t]{3}{*}{ Tapajos } & $334 \pm 15$ & +2.0 & - & - & Disturbed & Pyle et al. (2008) \\
\hline & & 244 & $(+1.0-+1.5)$ & - & - & - & Vieira et al. (2004) \\
\hline & & 335 & - & - & - & - & Figueira et al. (2008) \\
\hline \multirow[t]{2}{*}{ West } & Rio Branco & 281 & $(+1.0-+1.5)$ & - & - & - & Vieira et al. (2004) \\
\hline & Antimary & - & - & 199 & $(+0.2-+6.9)$ & $\begin{array}{l}\text { RIL, bamboo } \\
\text { dominated }\end{array}$ & De Oliveira et al. (2013) \\
\hline
\end{tabular}

AGB increment due to tree growth and recruitment in the unlogged block $(3.4+1.4=$ 4.8 $\left.\mathrm{Mg} \mathrm{ha}^{-1} \mathrm{y}^{-1}\right)$ was comparable to values obtained from other sites of natural forests, including BIONTE (central Amazon, 3.4 Mg ha $\mathrm{M}^{-1}$ - Chambers et al. 2004), Paragominas (5.7 and 5.3 $\mathrm{Mg} \mathrm{ha}^{-1} \mathrm{y}^{-1}-$ Mazzei et al. 2010), and Nouragues (French Guiana, eastern Amazon, 4.2 Mg ha-1 $\mathrm{y}^{-1}$ - Chave et al. 2008). If the annual AGB loss due to tree mortality in the unlogged block was the same as in the logged blocks $\left(-3.8 \mathrm{Mg} \mathrm{ha}^{-1}\right.$ $\left.\mathrm{y}^{-1}\right)$, the net annual increment in AGB would be $+1.0 \mathrm{Mg} \mathrm{ha}^{-1} \mathrm{y}^{-1}$, which falls within the range of values from natural forests in the Amazon region (Tab. 4). Therefore, excluding tree mortality, the time-frame for $A G B$ dynamics in the unlogged forest block in Itacoatiara is consistent with other natural forests in the Amazon. Since no evidence of destructive disturbances (e.g., storm or fire) was found in the unlogged plots during fieldwork in 2013, the reason for the large decrease in AGB, or great mortality, in the unlogged block remains unclear. The overall change of AGB (-4.4 Mg ha $\left.{ }^{-1} \mathrm{y}^{-1}\right)$ was slightly out of the range of the annual $A G B$ increase $\left(-4.1\right.$ to $\left.+4.6 \mathrm{Mg} \mathrm{ha}^{-1} \mathrm{y}^{-1}\right)$ observed in old-growth terra firme forests used for long-term monitoring in the central and eastern Brazilian Amazon (Baker et al. 2004).

\section{$A G B$ recovery in logged forest}

By 5-15 years after selective logging, the net annual $A G B$ increment in the smallest trees $(10-20 \mathrm{~cm} \mathrm{dbh})$ from the later-logged blocks and the smaller trees $(20-30 \mathrm{~cm}$ $\mathrm{dbh}$ ) from the earlier-logged block was significantly positive (Fig. 2b). Moreover, the logged blocks had less AGB in small and medium-sized trees (10-40 cm dbh) than the unlogged block (Fig. 2a). These results indicate that the AGB of small and mediumsized trees still tend to increase in the logged forest blocks. According to our projections, the AGB of the logged forest would be almost fully restored within 14 years after logging (Fig. 1b), which is a much shorter period than the cutting cycle (i.e., 25 years) detailed in the PWA's management plan.

Post-logging growth patterns of remaining trees differed greatly by tree size in terra firme forests in the Amazon. For example, Figueira et al. (2008) reported that small and medium-sized trees $(10-55 \mathrm{~cm}$ $\mathrm{dbh}$ ) within $30 \mathrm{~m}$ of canopy gaps began to increase in diameter growth within several years after selective logging. On the other hand, Mazzei et al. (2010) indicated that large trees $(>60 \mathrm{~cm}$ dbh) had greater diameter growth than smaller trees, and substantially contributed to AGB growth during the early recovery stage. The significant increase in AGB in the smallest and largest trees in the later-logged blocks of our study site (Itacoatiara) did not correspond with the patterns of these two previous studies (Fig. 2b). Conversely, West et al. (2014) reported that smaller and larger trees had decreased AGB 16 years after selective logging, whereas medium-sized trees $(20-60 \mathrm{~cm} \mathrm{dbh}$ ) contributed to $A G B$ restoration. More information of the relationship between individual-level growth response and the overall recovery process of $A G B$ is required to understand the factors causing such variation in post-logging biomass recovery in the Amazon Basin.

Our logistic growth model anticipated an average $A G B$ recovery period of 14 years after selective logging at a harvest intensity of 1.9 trees $\mathrm{ha}^{-1}$. The expected annual increment in AGB 8-10 years after logging (2.13.5 Mg ha-1 $\mathrm{y}^{-1}$ ) was very close to the observed values $10-15$ years (2.5 Mg ha- $\mathrm{y}^{-1}$ ) and 5-9 years (3.8 Mg ha-1 $\mathrm{y}^{-1}$ ) after logging (Tab. 3). These expected and observed annual increments in AGB were also equiva- 
Tab. 5 - Selective logging intensity and AGB recovery period in Amazonian terra firme forests. (a): Estimated from timber volume based on an average log volume of $6.3 \mathrm{~m}^{3}$ $\log ^{-1}$ in the Brazilian Amazon region (Uhl \& Vieira 1989, FAO 1997). (b): A model for total wood volume.

\begin{tabular}{|c|c|c|c|c|c|}
\hline Region & Site & $\begin{array}{l}\text { Logging } \\
\text { intensity } \\
\left(\mathrm{n} \mathrm{ha}^{-1}\right)\end{array}$ & $\begin{array}{c}\text { Recovery } \\
\text { period } \\
\text { (yrs) }\end{array}$ & Condition & Reference \\
\hline Central & Itacoatiara & 1.9 & 14 & RIL, model & This study \\
\hline \multirow[t]{8}{*}{ East } & \multirow[t]{7}{*}{ Paragominas } & 3 & 15 & \multirow[t]{3}{*}{ RIL, model } & \multirow[t]{3}{*}{ Mazzei et al. (2010) } \\
\hline & & 6 & 51 & & \\
\hline & & 9 & 88 & & \\
\hline & & 4.5 & 16 & RIL, observed & \multirow{2}{*}{ West et al. (2014) } \\
\hline & & 5.6 & $>16$ & $\begin{array}{l}\text { Conventional, } \\
\text { observed }\end{array}$ & \\
\hline & & $10.3^{(a)}$ & 10 & RIL, model ${ }^{(b)}$ & \multirow[t]{2}{*}{ Valle et al. (2007) } \\
\hline & & - & $35-40$ & $\begin{array}{l}\text { Conventional, } \\
\text { model }\end{array}$ & \\
\hline & \multirow[t]{2}{*}{ Paracou } & 10.4 & $\begin{array}{r}45 \\
>100\end{array}$ & $\begin{array}{l}\text { Conventional, } \\
\text { model }\end{array}$ & Blanc et al. (2009) \\
\hline West & & 20.6 & $\begin{array}{r}>100 \\
4\end{array}$ & & \\
\hline West & Antimary & & & bamboo dominated & (2013) \\
\hline
\end{tabular}

lent to the mean value $\left(2.7 \mathrm{Mg} \mathrm{ha}^{-1} \mathrm{y}^{-1}\right)$ that was estimated from the data of 79 permanent sample plots across the Amazon Basin (Rutishauser et al. 2015). Tab. 5 summarizes available data of the relationship between logging intensity and estimated AGB recovery period from previously studies that examined in terra firme forests in the Amazon. Here, both conventional logging and RIL were included for reviewing effect of logging intensity on AGB recovery period. $A$ selectively logged terra firme forest in Paragominas, east Amazon, took 16 years to regain its original $A G B$ after harvesting at an intensity of 4.5 trees ha ${ }^{-1}$ using the RIL technique (West et al. 2014 - Tab. 5). Likewise, a simple simulation calculated an AGB recovery period of 15 years for terra firme forests in Paragominas that selectively logged at 3 trees ha ${ }^{-1}$ (Mazzei et al. 2010). Our projection of the AGB recovery period (14 years) agrees with these results from the forests of eastern Amazon, suggesting that Amazonian terra firme forests could regain their original $A G B$ stock within a dozen years after selective logging at an intensity of several trees $\mathrm{ha}^{-1}$ and proper logging techniques. However, there are some exceptions for the AGB recovery period. A bamboo-dominated rain forest in Antimary, west Amazon, recovered its AGB within only 4 years after selective logging at 6.9 $\mathrm{m}^{3} \mathrm{ha}^{-1}$ (De Oliveira et al. 2013), equivalent to 1.1 trees ha-1 logging (Tab. 5). This quick recovery appeared to be caused by the disappearance of the dominant bamboo because of the specific logging operation and rapid growth of residual trees around the gaps (De Oliveira et al. 2013). The recovery period would be drastically prolonged if further intensified harvesting or conventional logging techniques were applied; for example, a simple simulation predicted that a logging intensity of 6 or 9 trees ha- ${ }^{-1}$ would require 51 or 88 years of $A G B$ recovery, respectively (Mazzei et al. 2010). Blanc et al. (2009) similarly reported that the recovery period in a terra firme forest would extend to 45 years if a strong harvest (10.4 trees ha $^{-1}$ ) was conducted using conventional logging techniques. These comparisons of $A G B$ recovery period suggest that logging intensity should be limited to $\leq 5$ trees $\mathrm{ha}^{-1}$ to ensure sustainable forest management while minimizing carbon emissions. According to the formula provided by Rutishauser et al. (2015), harvesting 5 trees $\mathrm{ha}^{-1}$ (approximately $31.5 \mathrm{~m}^{3} \mathrm{ha}^{-1}$ ) would result in a $16.7 \%$ loss of $A G B$ under RIL management and 22.5 years for recovery to the initial AGB level. A logging intensity of $\leq 5$ trees ha ${ }^{-1}$ and $A G B$ recovery period of 22.5 years would be acceptable to forest managers.

\section{Conclusions}

Our study was a first trial to quantitatively evaluate RIL operated in tropical forests of the central Amazon. Comparisons with previous studies mainly conducted in other regions of the Amazon suggested that logging intensity and the estimated $A G B$ recovery period were appropriate and likely acceptable parameters for forest management. However, maintaining tree biomass and healthy biodiversity are prerequisites for ecologically sound forest management. This study examined the process of biomass recovery in only living trees. Even after clear-cutting, AGB of trees in an Atlantic forest in Brazil recovered to a level equivalent to that of nearby preserved forest within 60 years (Lindner \& Sattler 2012). Carbon pools recovered more quickly than tree and epiphyte species richness in tropical secondary forests (Martin et al. 2013). Organic carbon stocks in soil also remained at a lower level than that measured in unlogged forest 45-50 years after selective logging (Chiti et al. 2016). Furthermore, the post-logging timber species composition and total economic value of forest stands did not recover beyond the first cut in Para state, Brazil (Richardson \& Peres 2016). Abiotic alterations from selective logging, that is, changes in light and soil conditions, raised mortality rates of major tree species in the central Amazon (Darrigo et al. 2016). Therefore, recovery not only of carbon pools but also of species composition for various taxa, and the regeneration of timber species should be further examined in order to propose a method of RIL that could achieve truly sustainable selective logging in the forests of the central Amazon.

\section{Acknowledgments}

The authors are indebted to Precious Woods Amazon Ltd. in Itacoatiara for their kind understanding and cooperation during our study, and to the Japan International Cooperation Agency (JICA) office in Manaus for its expert management of the research project. We thank the members of the international cooperative research project "Carbon Dynamics of Amazonian Forests" for their energetic support. We also thank Antonio Raimundo Gomes de Souza, Wanderley de Lima Reis, and Manoel Tiago Martins da Silva for their powerful support in our field work. Financial support was provided by the Instituto Nacional de Pesquisas da Amazônia (INPA) and the Science and Technology Research Partnership for Sustainable Development (SATREPS) program funded by the Japan Science and Technology Agency (JST) and JICA. All field activity in 2006 was performed by the INPA project, and the surveys in 2010 and 2012-2013 were conducted by the JST-JICA project.

\section{References}

Asner GP, Knapp DE, Broadbent EN, Oliveira PJC, Keller M, Silva JN (2005). Selective logging in the Brazilian Amazon. Science 310: 480-482. doi: 10.1126/science.1118051

Baker T, Phillips O, Malhi Y, Almeida S, Arroyo L, Di Fiore A, Erwin T, Higuchi N, Killeen T, Laurance $S$, Laurance $W$, Lewis $S$, Monteagudo $A$, Neill D, Vargas $P$, Malhi Y, Almeida S, Martínez R, Nunez VP, Vasquez MR (2004). Increasing biomass in Amazonian forest plots. Philosophical Transactions of the Royal Society B: Biological Sciences 359: 353-365. - doi: 10.1098/rstb.20 03.1422

Blanc L, Echard M, Herault B, Bonal D, Marcon E, Chave J, Baraloto C (2009). Dynamics of aboveground carbon stocks in a selectively logged tropical forest. Ecological Applications 19: 13971404. - doi: 10.1890/08-1572.1

Broadbent E, Asner G, Keller M, Knapp D, Knapp D, Oliveira P, Silva J (2008). Forest fragmentation and edge effects from deforestation and selective logging in the Brazilian Amazon. Biological Conservation 141: 1745-1757. - doi: 10.1016/j.biocon.2008.04.024

Chambers JQ, Higuchi N, Teixeira LM, Dos Santos J, Laurance SG, Trumbore SE (2004). Response of tree biomass and wood litter to disturbance in a Central Amazon forest. Oecologia 141: 596611. - doi: 10.1007/s00442-004-1676-2 
Chave J, Olivier J, Bongers F, Châtelet P, Forget $P M$, Van Der Meer $P$, Norden N, Riéra B, Charles-Dominique $P$ (2008). Above-ground biomass and productivity in a rain forest of eastern South America. Journal of Tropical Ecology 24: 355-366. - doi: 10.1017/S0266467408005075 Chazdon RL, Letcher SG, Van Breugel M, Martínez-Ramos M, Bongers F, Finegan B (2007). Rates of change in tree communities of secondary Neotropical forests following major disturbances. Philosophical Transactions of the Royal Society B: Biological Sciences 362: 273289. - doi: 10.1098/rstb.2006.1990

Chiti T, Perugini L, Vespertino D, Valentini R (2016). Effect of selective logging on soil organic carbon dynamics in tropical forests in central and western Africa. Plant and Soil 399: 283-294. - doi: 10.1007/s11104-015-2697-9

Darrigo MR, Venticinque EM, Dos Santos FAM (2016). Effects of reduced impact logging on the forest regeneration in the central Amazonia. Forest Ecology and Management 360: 5259. - doi: 10.1016/j.foreco.2015.10.012

De Castilho CV, Magnusson WE, De Araujo RNO, Luizao RCC, Luizao FJ, Lima AP, Higuchi N (2006). Variation in aboveground tree live biomass in a central Amazonian forest: effects of soil and topography. Forest Ecology and Management 234: 85-96. - doi: 10.1016/j.foreco. 2006.06.024

De Graaf NR, Poels RLH (1990). The Celos Management System: a polycyclic method for sustained timber production in South American rainforest. In: "Alternatives to Deforestation: Steps toward Sustainable Use of the Amazon Rain Forest" (Anderson AB ed). Columbia University Press, New York, USA, pp. 116-127.

De Oliveira MVN, Guarino EDS, Oliveira LC, Ribas LA, Acuna MHA (2013). Can forest management be sustainable in a bamboo dominated forest? A 12-year study of forest dynamics in western Amazon. Forest Ecology and Management 310: 672-679. - doi: 10.1016/j.foreco.2013.09.008

FAO (1997). Environmentally sound forest harvesting: testing the applicability of the FAO model code in the Amazon in Brazil. Forest Harvesting Case Study, FAO, Rome, Italy, pp. 78.

FAO (2002). Environmentally sound forest harvesting in Brazil: assessment of regeneration and environmental impacts four years after harvesting. Forest Harvesting Case Study, FAO, Rome, Italy, pp. 34.

Figueira A, Miller SD, De Sousa CAD, Menton MC, Maia AR, Rocha HR, Goulden ML (2008). Effects of selective logging on tropical forest tree growth. Journal of Geophysical Research: Biogeosciences 113: GooB05. - doi: 10.1029/2007jgo 00577

Fonseca W, Rey BJM, Alice FE (2011). Carbon accumulation in the biomass and soil of different aged secondary forests in the humid tropics of Costa Rica. Forest Ecology and Management 262: 1400-1408. - doi: 10.1016/j.foreco.20 11.06.036

Gelman A, Rubin DB (1992). Inference from iterative simulation using multiple sequences. Statistical Science 7: 457-472. - doi: 10.1214/ss/11770 11136

Huang M, Asner G (2010). Long-term carbon loss and recovery following selective logging in Amazon forests. Global Biogeochemical Cycles
24: GB3028. - doi: 10.1029/2009GB003727 Kashian DM, Romme WH, Tinker DB, Turner MC (2013). Postfire changes in forest carbon storage over a 300-year chronosequence of Pinus contorta-dominated forests. Ecological Monographs 83: 49-66. - doi: 10.1890/11-1454.1

Laurance WF, Laurance SG, Ferreira LV, RankinDe Merona JM, Gascon C, Lovejoy TE (1997). Biomass collapse in Amazonian forest fragments. Science 278: 1117-1118. - doi: 10.1126/scien ce.278.5340.1117

Laurance WF, Fearnside PM, Laurance SG, Delamonica P, Lovejoy TE, Rankin-De Merona J, Chambers JQ, Gascon C (1999). Relationship between soils and Amazon forest biomass: a landscape-scale study. Forest Ecology and Management 118: 127-138. - doi: 10.1016/s0378-1127 (98)00494-0

Lindner A, Sattler D (2012). Biomass estimations in forests of different disturbance history in the Atlantic Forest of Rio de Janeiro, Brazil. New Forests 43: 287-301. - doi: 10.1007/s11056-0119281-9

Martin PA, Newton AC, Bullock JM (2013). Carbon pools recover more quickly than plant biodiversity in tropical secondary forests. Proceedings of the Royal Society B: Biological Sciences 280: 20132236. - doi: 10.1098/rspb.2013.2236

Mazzei L, Sist P, Ruschel A, Putz FE, Marco P, Pena W, Ferreira JER (2010). Above-ground biomass dynamics after reduced-impact logging in the Eastern Amazon. Forest Ecology and Management 259: 367-373. - doi: 10.1016/j. forec0.2009.10.031

Mora F, Martínez-Ramos M, Ibarra-Manríquez G, Pérez-Jiménez A, Trilleras J, Balvanera P (2015). Testing chronosequences through dynamic approaches: time and site effects on tropical dry forest succession. Biotropica 47: 38-48. doi: 10.1111/btp.12187

Pan Y, Birdsey RA, Fang J, Houghton R, Kauppi PE, Kurz WA, Phillips OL, Shvidenko A, Simon LL, Canadell JG, Ciais P, Jackson RB, Pacala SW, McGuire AD, Piao S, Rautiainen A, Sitch $S$, Hayes D (2011). A large and persistent carbon sink in the world's forests. Science 333: 988993. - doi: $10.2307 / 27978486$

Pearson TRH, Brown S, Casarim F (2014). Carbon emissions from tropical forest degradation caused by logging. Environmental Research Letters 9 (3): 034017. - doi: 10.1088/1748-9326/ 9/3/034017

Peña-Claros M, Fredericksen TS, Alarcón A, Blate GM, Choque U, Leaño C, Licona JC, Mostacedo B, Pariona W, Villegas Z, Putz FE (2008). Beyond reduced-impact logging: silvicultural treatments to increase growth rates of tropical trees. Forest Ecology and Management 256: 1458-1467. - doi: 10.1016/j.foreco.2007.11.013.

Picard N, Gourlet-Fleury S, Forni E (2012). Estimating damage from selective logging and implications for tropical forest management. Canadian Journal of Forest Research 42: 605613. - doi: 10.1139/x2012-018

Pinard MA, Cropper WP (2000). Simulated effects of logging on carbon storage in dipterocarp forest. Journal of Applied Ecology 37: 267283. - doi: 10.1046/j.1365-2664.2000.00488.x

Pinard M, Putz FE (1996). Retaining forest biomass by reducing logging damage. Biotropica 28: 278-295. - doi: 10.2307/2389193
Plummer M, Best N, Cowles K, Vines K (2006). CODA: Convergence diagnosis and output analysis for MCMC. R News 6: 7-11. [online] URL: http://oro.open.ac.uk/22547/

Putz FE, Zuidema PA, Synnott T, Peña-Claros M, Pinard MA, Sheil D, Vanclay JK, Sist P, GourletFleury S, Griscom B, Palmer J, Zagt R (2012). Sustaining conservation values in selectively logged tropical forests: the attained and the attainable. Conservation Letters 5: 296-303. doi: 10.1111/j.1755-263X.2012.00242.x

Pyle EH, Santoni GW, Nascimento HEM, Hutyra LR, Vieira S, Curran DJ, Van Haren J, Saleska SR, Chow VY, Carmago PB, Laurance WF, Wofsy SC (2008). Dynamics of carbon, biomass, and structure in two Amazonian forests. Journal of Geophysical Research - Biogeosciences 113: Goo Bo8. - doi: 10.1029/2007JG000592

Richardson VA, Peres CA (2016). Temporal decay in timber species composition and value in Amazonian logging concessions. PLoS ONE 11: 1-22. - doi: 10.1371/journal.pone.0159035

Rutishauser E, Herault B, Baraloto C, Blanc L, Descroix L, Sotta ED, Ferreira J, Kanashiro M, Mazzei L, De Oliveira MVN, De Oliveira LC, Pena-Claros $M$, Putz FE, Ruschel AR, Rodney $K$, Roopsind A, Shenkin A, Da Silva KE, De Souza CR, Toledo M, Vidal E, West TAP, Wortel V, Sist $P$ (2015). Rapid tree carbon stock recovery in managed Amazonian forests. Current Biology 25: R787-R788. - doi: 10.1016/j.cub.2015.07.034 Saatchi SS, Houghton RA, Alvala R, Soares JV, Yu $Y$ (2007). Distribution of aboveground live biomass in the Amazon basin. Global Change Biology 13: 816-837. - doi: 10.1111/j.1365-2486.2007. 01323.x

Silva RP (2007). Alometria, estoque e dinâmica da biomassa de florestas primárias e secundárias na regiaõ de Manaus (AM) [Allometry, stock, and dynamics of biomass in primary and secondary forests in Manaus region, Amazonas]. PhD thesis, Tropical Forest Science Course, Federal University of Amazonas and National Institute of Amazonian Research, Manaus, Brazil, pp. 152. [in Portuguese with English summary]

Sist P, Ferreira FN (2007). Sustainability of reduced-impact logging in the Eastern Amazon. Forest Ecology and Management 243: 199-209. - doi: 10.1016/j.foreco.2007.02.014

Sist P, Blanc L, Mazzei L, Baraloto C, Aussenac R (2012). Current knowledge on overall post-logging biomass dynamics in Northern Amazonian forests. Bois et Forets des Tropiques 314: 41-49. - doi: 10.19182/bft2012.314.a20489

Sist P, Mazzei L, Blanc L, Rutishauser E (2014). Large trees as key elements of carbon storage and dynamics after selective logging in the Eastern Amazon. Forest Ecology and Management 318: 103-109. - doi: 10.1016/j.foreco.2014. 01.005

Suwa R, Sakai T, Dos Santos J, Da Silva RP, Kajimoto T, Ishizuka M, Higuchi N (2013). Significance of topographic gradient in stem diameter-height allometry for precise biomass estimation of a tropical moist forest in the central Amazon. JARQ - Japan Agricultural Research Quarterly 47: 109-114. - doi: 10.6090/jarq.47.109 Suwa R, Silva F, José A, Lima N, Carlos A, Pinto $M$, Santos J (2016). Changes in forest structure and biomass over ten years in a lowland Ama- 
zonian forest. JARQ - Japan Agricultural Research Quarterly 50: 379-386. - doi: 10.6090/ jarq.50.379

Uhl C, Vieira ICG (1989). Ecological impacts of selective logging in the Brazilian Amazon - a case-study from the Paragominas region of the state of Para. Biotropica 21: 98-106. - doi: $10.2307 / 2388700$

Valle D, Phillips P, Vidal E, Schulze M, Grogan J, Sales M, Van Gardingen P (2007). Adaptation of a spatially explicit individual tree-based growth and yield model and long-term comparison between reduced-impact and conventional logging in eastern Amazonia, Brazil. Forest Ecology and Management 243: 187-198. - doi: 10.1016/j.foreco.2007.02.023

Vieira S, De Camargo PB, Selhorst D, Da Silva R, Hutyra L, Chambers JQ, Brown IF, Higuchi N, Dos Santos J, Wofsy SC, Trumbore SE, Martinelli LA (2004). Forest structure and carbon dynamics in Amazonian tropical rain forests. Oecologia 140: 468-479. - doi: 10.1007/s00442- 004-1598-z

Webster CA, Callejon DP (1998). Precious Woods, Ltd. In: "The Business of Sustainable Forestry: Case Studies" (A project of the Sus tainable Forestry Working Group). Island Press, Chicago, USA, pp. 13: 1-13. 24.

West TAP, Vidal E, Putz FE (2014). Forest biomass recovery after conventional and reduced-impact logging in Amazonian Brazil. Forest Ecology and Management 314: 59-63. - doi: 10.1016/ j.foreco.2013.11.022 